УДК $81: 81$ '373.7:398.9

DOI https://doi.org/10.26661/2414-1135-2021-84-22

\title{
СТРУКТУРНО-СЕМАНТИЧНІ ОСОБЛИВОСТІ УКРАЇНСЬКИХ ПАРЕМІЙ З ТОПООНОМАСТИЧНИМ КОМПОНЕНТОМ
}

\author{
Мамчич I. П. \\ кандидат філологічних наук, доиент, \\ дочент кафедри гуманітарної підготовки, \\ філософії та митної ідентифікачї культурних иінностей \\ Університет митної справи та фінансів \\ пр. Вернадського, 2/4, Дніпро, Украӥна \\ orcid.org/0000-0002-7921-5877 \\ innamam11@gmail.com
}

Ключові слова: пареміологія, прислів'я, приказка, топонім, гідронім, ойконім.
У статті проаналізовані паремії 3 топонімічним компонентом. За тривалий час наукового вивчення фразеологічного багатства української мови, а прислів'я й приказки, зважаючи на усталеність їх оформлення, відтворюваність, експресивність, національні коди тощо, традиційно уналежнюють до фразеології, пареміологія неодноразово ставала предметом дослідження. Утім, вплив значення топонімів на семантику паремії, уживання окремих різновидів топонімів у пареміях залишався поза увагою вчених. Не акцентовано також на структурних особливостях прислів ”ів і приказок зі топоономастичним компонентом.

Дослідження дев'яноста однієї паремії з топонімічним компонентом уможливило висновки про те, що найуживанішими в їх складі є топоніми у формі називного й місцевого відмінків, ймовірніше, через те, що потрібно було назвати місцевість (Наш Луг - батько, а Січ - мати, от де треба помирати) і вказати на неї (Або будем на Русі, або пропадемо усі). Топоніми у складі прислів’їв і приказок здебільшого стосуються назв українських міст і територій (Київ, Крим, Русь), менш уживаними $\epsilon$ іншомовні назви (Краків, Рим). Лише в поодиноких пареміях спостережено гідроніми, найчастіше потамонім Дунай, що виявилося неочікуваним результатом, бо водойми відіграють важливе значення в українській дійсності. Також з'ясовано, що значення всієї паремії найчастіше залежить від семантики складника-топоніма (Добувся, як швед під Полтавою), побіжно зазначивши, що він може відбивати як реальний географічний об'єкт (Полтава, Теплинський ліс), так і вигаданий (Брехунівка). Прислів'я і приказки 3 топоономастичним компонентом, як й інші паремії, мають римовану структуру, витворювану іменником і дієсловом або поєднанням іменника 3 іншими частинами мови, що служить легшому запам'ятовуванню та відтворюванню. 3 боку синтаксичної будови паремії 3 компонентами-топонімами становлять різноманітні види речень.

Перспективою дослідження вважаємо ретроспективне вивчення різних груп топонімів у складі паремій, 3'ясування синтагматичнопарадигматичних відношень між такими одиницями, дослідження їх, наприклад, укогнітивному, етнопсихологічному,лінгвокультурологічному, дискурсивному тощо напрямах. 


\title{
STRUCTURAL-SEMANTIC PECULIARITIES OF UKRAINIAN PAREMIAS WITH TOPOONOMASTIC COMPONENT
}

\author{
Mamchych I. P. \\ Candidate of Philological Sciences, Associate Professor, \\ Associate Professor at the Department of Humanities, \\ Philosophy and Customs Evaluation of Cultural Values \\ University of Customs and Finance \\ Vernadskyi Ave., 2/4, Dnipro, Ukraine \\ orcid.org/0000-0002-7921-5877 \\ innamam11@gmail.com
}

Key words: paremiology, proverb, saying, toponym, hydronym, oikonym.

\begin{abstract}
Paremias with toponymic component are analized in the article. For a long period of academic studies of the Ukrainian phraseological diversity paremiology became the subject of scrutinizing as proverbs and sayings with their types of formation, expressiveness, national codes etc. traditionally belong to phraseology. Although the influence of toponyms meaning to the semantics of paremias, the use of certain separate types of toponyms in paremias is out of the scientists' attention. Structural peculiarities of proverbs and sayings with topoonomastic component are not studied as well.

The study of ninety-one paremias with topoonomastic component makes it possible to come to the conclusion that the most frequently used among them are toponyms in Nominative and Prepositional Case mostly because of the necessity to name a certain destination (Наш Луг - батько, а Січ - мати, от де треба помирати) and point it out (Або будем на Русі, або пропадемо yci). Toponyms as a part of proverbs and sayings mostly deal with naming of Ukrainian cities and territories (Київ, Крим, Русь), foreign names are less used (Краків, Рим). Only in some paremias hydronyms, mostly potamonym the Danube, are found which was quite strange as water takes an important part in Ukrainian reality. It is also found out that the meaning of a paremia in most cases depends on the semantics of a toponym part (Добувся, як швед під Полтавою), taking into account the fact that it can demonstrate not only a real geographic object (Полтава, Теплинський ліс) but also an invented one (Брехунівка). Proverbs and sayings with topoonomastic component as well as the other paremias have a rhyme structure which is formed with the help of a noun and a verb or a combination of a noun with other parts of speech that helps to remember it easier and use. From the point of view of a syntactic structure, paremias with toponyms-components help to create various types of sentences.

The prospective of the research is considered to be a retrospective study of different groups of toponyms in paremias, analysis of syntagmaticparadigmatic relations between such units, their study in terms of cognitive, ethnopsychological linguocultural, discourse etc. directions.
\end{abstract}

Постановка проблеми. Однією із численних груп у генетичній класифікації фразеологічного матеріалу нашого народу є прислів'я та приказки - паремії. Через неусталеність обсягу поняття «паремія» в науковій розвідці спиратимемося на визначення професора М.Т. Демського: прислів'я - стійкий вислів переважно фольклорного походження, в якому зафіксований практичний досвід народу та його оцінка різних подій та явищ. Прислів'я на відміну від приказок - це самостійне судження, інтонаційно й граматично оформлене як просте (Дружній череді й вовк не страшний) або складне (Біда тому волові, котрого корова коле) речення [1]; приказка - стійкий вислів здебільшого фольклорного походження, який образно розкриває певне явище насамперед iз погляду на його емоційно-експресивну оцінку. Приказки на відміну від прислів 'їв висловлюють незавершену думку, $\epsilon$ частиною судження, що має форму незамкненого кліше [2]. 
Власні назви належать до мовних універсалій - вони є в усіх мовах світу, але в кожній мають свої ознаки. Сукупність усіх власних назв мови становить іï ономастичний простір, який серед інших рис також диференціює різні мови. Через те вивчення ономастичних назв в окремих мовах не втрачає своєї актуальності. I хоч до складу паремій дослідники уналежнюють примовки, загадки, прикмети, «ділові» вислови, повір'я, «віщі» сни, ворожби, задачі, головоломки, скоромовки, пустомолки, замовляння, небилиці, нісенітниці, одномоментні анекдоти, казкові формули тощо [3], предметом розгляду в статті стали саме прислів'я та приказки з топонімічним компонентом.

Мета й завдання статті. Метою статті $€$ визначення структурних особливостей паремій із топоономастичним компонентом і встановлення впливу топонімів на загальне значення прислів 'їв і приказок. Мета передбачає виконання таких завдань дослідження, як установлення семантичних маркерів паремій із топоономастичним компонентом; створення семантичної класифікації аналізованих паремій і з'ясування засобів витворення рими в пареміях.

Предмет та об’єкт дослідження. Предметом наукового зацікавлення в статті стали прислів'я та приказки з топонімічним компонентом, а об'єктом - пареміологія української мови, до складу якої їх уналежнюють.

Виклад основного матеріалу. Українська наука вивчення фразеологічних одиниць із різними семантичними компонентами має багато напрацювань, наприклад, наукові розвідки В.М. Бойко й Л. Б. Давиденко [4], О.А. Пономарьової [5], О.М. Каракуця [6], В.Д. Ужченка [7], О.А. Мороз [8; 9], О.В. Омельяненко [10] та інших. Активно досліджується ономастичний простір, зокрема й паремій (О.А. Куцик, М.Д. Колечко [11; 12], Н.А. Ковальська [13] та інші). Утім, комплексному структурному-семантичному аналізу саме топоономастичного компонента в українських прислів'ях і приказках приділено ще мало уваги.

Прислів їв і приказок, які $є$ різновидом, із топоономастичним компонентом у досліджуваній збірці виділено дев'яносто одну номінацію.

Більшість паремій, що були залучені до аналізу, багатокомпонентні, тобто мають у своєму складі більше, ніж три слова: Бідний, бідний, пане Степане! Не попав, небоже, на Запоріжжя, не найшов гаразд иляху [14, с. 203], Прийшли з Бозни й чорзна-що верзли [14, с. 174], Не добереш, де Рим, де Крим, де попова груша [14, с. 174], Ha Поділлю хліб по кіллю, а ковбасами хліб загороджений [14, с. 175] тощо. Але трапляються серед них і дво-, трикомпонентні: Велика Руська мати (земля Руська) [14, с. 205], Не зразу Львів збудовано [14, с. 288], Городня - голодня [14, с. 288], Подариш пойхав у Париж [14, с. 314] та інші.
Усі топоніми у складі паремій виражені іменниками в тому чи іншому відмінку, найпоширенішими 3 яких $є$ :

- називний (Що таке Америка, спитай у Каленика: їздив по гроші, а привіз гниди та воші [14, с. 15], Де Папа, там і Рим [14, с. 132], He добереш, де Рим, де Крим, де попова груша [14, с. 174], Тверда Русь усе перебуде [14, с. 205], Наш Луг - батько, а Сіи - мати, от де треба помирати [14, с. 209]);

- родовий (Старший Галич відо Львова $[14$, c. 288]);

- знахідний (Пройти Крим і Рим [14, с. 80]);

- місцевий (I в Києві, $i$ в Харкові - всюди злидні однакові $[14$, с. 30], Ой на річиі, на Йордані нема хліба, підем далі [14, с. 74], Або будем на Pyci, або пропадемо усі [2, с. 201], Мазеnа в Полтаві подавивсь галушкою [14, с. 206], Піти на Низ, щуоб ніхто голови не гриз [14, с. 207], Як козак у Лузі [14, с. 209]).

Майже половина 3 досліджуваних паремій (сорок одна) має римовану структуру. Рима може охоплювати:

- усю паремію: I у Відні люди бідні [14, с. 15], I в Києві, $і$ в Харкові - всюди злидні однакові [14, с. 30], Піди за Бескиди - не збудеш біди [14, с. 42], Від Києва до Кракова - всюди біда однакова [14, с. 42], Ой на річиі, на Йордані нема хліба, підем далі [14, с. 74], Гола та Теплинський ліс, де чумаків бере біс [14, с. 91], Пани однакові, що в нас, щзо в Харкові [14, с. 109], Заӥхав за Дунай - та й додому не думай [14, с. 205], Іди, зима, до Бучина, бо вже нам надокучила $[14$, c. 240$]$ тощо;

- окремо дві зазвичай рівноправні частини виразу: ${ }^{*} 1$ Що таке Америка, спитай у Каленика; 2 Їздив по грощі, а привіз гниди та вощі [14, с. 15], 1 На кого біда нападе, то до Києва йде; 2 А як біда минеться, то він $і$ з Броварів вернеться [14, с. 42], 1 Кам'янець - вінець; 2 кругом вода, а всередині біда [14, с. 288], 1 Обізвавсь Яготин: «Ніжин мені побратим», 2 Ніжин каже: «С у степу Ромен, та й той мені не рівен” [14, с. 288] та інші.

Трапляються й такі паремії, в яких римованою $є$ лише частина, навантажена основним смислом, або між двома римованими частинами $є$ неримовані: На Поділлю хліб по кіллю, а ковбасами хліб загороджений [14, с. 175], Сосниця-розкішниця, великі вжитки: кругом вода, а всередині біда $[14$, с. 288$]$ тощо. Римованість фрази сприяє легшому запам'ятовуванню.

$\mathrm{y}$ творенні рим у пареміях із топоономастичним компонентом беруть участь різні частини мови. За таким критерієм можна виділити такі види рим:

$1^{*} 1,2$ - частини виразу. 


\section{1. Граматична:}

- іменникова (У Попівці хліб по копійці, а в Перекопі хліб по копі [14, с. 288], 3 Вересочі повилазили очі [14, с. 288], Вези овес і до Парижа, а не буде 3 вівса рижа [14, с. 584]);

- дієслівна (На кого біда нападе, то до Києва йде; а як біда минеться, то він $i$ з Броварів вернеться [14, с. 42], Про Київ не жахайсь, Волиня пригортайсь, а Покуття тримайсь [14, с. 288]).

2. Неграматична:

- іменник і дієслово (Більше, турок, за Дунай виходити не думай [14, с. 206], Піти на Низ, щэоб ніхто голови не гриз [14, с. 207]);

- іменник і прикметник (I у Відні люди бідні [14, с. 15], I в Києві, і в Харкові - всюди злидні однакові $[14$, с. 30$])$;

- іменник і прислівник (Дон Доном, а найкраме дома $[14$, с. 201]);

- іменник і займенник (Або будем на Pусі, або пропадемо усі [14, с. 201]) тощо.

Слід зазначити, що більшість паремій - це речення різних типів. За метою висловлення можна виділити:

- розповідні (На кого біда нападе, то до Кисва йде; а як біда минеться, то він $і$ з Броварів вернеться [14, с. 42], Пани однакові, щио в нас, щчо в Харкові [14, с. 109], Ворскла - річка невеличка, берега ламає; хто в Полтаві не буває, той лиха не знає [14, с. 288], Язик доводить до Києва, а часом до кия [14, с. 482], Їхала Хима з Срусалима: тарахкотілка теркоче, а коник бігти не хоче [14, с. 608], У городі бузина, а в Києві дядько, тим я тебе полюбила, щуо на п'яті перстень $[14$, c. 780$])$;

- питальні (але всі вони риторичні) ( $A$ ви, часом, не з Брехунівки? [14, с. 171], Де ти поза Уманню ходии? [14, с. 417]);

- спонукальні (Iди, зима, до Бучина, бо вже нам надокучила [14, с. 240], Про Київ не жахайсь, Волиня пригортайсь, а Покуття тримайсь [14, с. 288], У Києві не женись, а в Ромні кобил не міняй $[14$, с. 288]).

За синтаксичною структурою паремії неоднорідні. Вони можуть мати структуру простих або складних речень. Серед простих можна виділити:

- двоскладні (I у Відні люди бідні [14, с. 15], Як хан долізе до Криму [14, с. 203], Мазепа в Полтаві подавивсь галушкою [14, с. 206], Золотоноша кругом хороша [14, с. 288], Подариш поӥхав у Париж [14, с. 314]);

- односкладні (Добувсь, як під Очаковим $[14$, c. 205]);

- поширені (Подарунки за Дніпром без штанів ходять [14, с. 314], Дурний і в Києві не купить розуму [14, с. 392], Поніс Харків Макогоненків [14, с. 480], Далеко п'яному до Києва [14, с. 500], Бігла собака у Петрівку через лід [14, с. 776]);
- непоширені (Городня - голодня [14, с. 288]); - повні (Стариий Галич відо Львова [14, с. 288], В Хоролі всього доволі [2, с. 288], Ніжин більи од Носівки тільки одною хатою $[14$, c. 288$])$;

- неповні (переважно у діалогах) («Здоров, брат! A відкіль ти?» - «3 Печенюг!» «A жінка $\epsilon$ ?» - «E!» - «A дітки?» «Аякже!»- «А хлібечь?» - «У-гу-гу» [14, с. 288],Відкіль? - 3 Ромна - А щчо? - Воли - Почім? - Без n'яти $[14$, с. 768$])$.

Серед складних спостережені:

- безсполучникові (Підеш до Печери-ляжеш спать без вечері [14, с. 214]);

- складносурядні (Або будем на Русі, або пропадемо усі [14, с. 201]);

- складнопідрядні (Гола та Теплинський ліс, де чумаків бере біс [14, с. 91], Не один Гаврилко, щоо в Полоиьку [14, с. 128], Не добереш, де Рим, де Крим, де попова груша [14, с. 174], Заїхав за Дунай-тайдодомунедумай [14, с. 205], Іди, зима, до Бучина, бо вже нам надокучила [14, с. 240]);

- змішані (із сурядним, підрядним і / або безсполучниковим зв'язком) (Що таке Америка, спитай у Каленика: їздив по гроші, а привіз гниди та воші [14, с. 15], На кого біда нападе, то до Києва йде; а як біда минеться, то він $і$ з Броварів вернеться [14, с. 42], Наш Луг - батько, а Січ-мати, от де треба помирати [14, с. 209], Про Київ не жахайсь, Волиня пригортайсь, а Покуття тримайсь [14, с. 288]).

Під час дослідження було виявлено, що найчастотнішим у стійких виразах виявився топонім Київ - наявний у чотирнадцятьох пареміях, тому що це місто завжди посідало центральне місце в історії України. Далі в спадній градації топоніми: Краків (у чотирьох пареміях), Puм (у чотирьох пареміях), Україна (у трьох пареміях), Русь (у трьох пареміях), Луг (у трьох пареміях), Крим (у трьох пареміях) тощо. По одному разу трапляються топоніми Волинь, Покуття, Чигирин, Америка, Бровари, Бескиди, Таращанці, Покошиці, Тростяниі, Париж, Печенюги, Яготин, Носівка, Хорол, Срусалим, Полочьк, Борзна, Очаків, Низ, Печера, Бучин, Бориспіль, Галич, Луцьк, Сосничі, Кам'янець, Городня, Перекоп, Конотоп.

За семантикою всі топоніми можна поділити (за класифікацією В.А. Жучкевича [15]) на топоніми, пов'язані $з$ фізико-географічними особливостями місцевості (за назвами річок - Борзна, Хорол, Полоцьк); топоніми, що вказують на місце розташування об'єктів (Низ, Запоріжжся, Луг, Покуття); фітотопоніми (Сосниия); зоотопоніми (Львів); топоніми релігійного й культового походження (Попівка); топоніми, пов'язані із соціально-економічними явищами (Бучин (назва села походить від назви рибальських плетених кошів 
«Бучи»); етноніми, пов'язані 3 назвами народів (Умань (назва походить від слова куман - так називали тюрків-половців, які володіли територією міста до польсько-литовських завоювань $[16$, c. 17])).

Нерідко значення всієї паремії залежить від прямого значення топоніму й / або пов'язане 3 певними історичними подіями. Наприклад, у паремії Гола та Теплинський ліс, де чумаків бере бic $[14$, c. 91] основний смисл закодовано в істоpiї Теплинського лісу. Колись у ньому жили гайдамаки, що нападали на чумаків і грабували їх або навіть убивали, тому й самій паремії топонім надає негативного відтінку значення.

Значення паремії Добувся, як швед під Полтавою [14, с. 206] витворилося 3 огляду на результат Полтавської битви - основної битви під час Великої Північної війни між арміями Карла XII й Петра I, що відбулася в 1709 році поблизу Полтави. Перемогу в ній здобули сили Петра I, а шведська армія під керівництвом Карла XII зазнала поразки.

Значення паремії Нещасна, як подільська корова $[14$, с. 185$]$ пояснюється тим, що на Поділлі корів запрягали замість волів для того, щоб обробляти землю.

Іноді ті чи ті топоніми в прислів'ях і приказках мовці вживають, щоб наголосити на певному негативному відтінку значення всього висловлення. Наприклад, прислів'я Попи однакові, щзо в нас, що в Кракові [14, с. 222] має негативну конотацію щодо священнослужителів і влади взагалі через те, що народ уважав більшість із них нечистими на руку, а в Кракові приблизно з 1000 року розташовувалася резиденція єпископа. За панування Казимира Відновителя це місто стало головною князівською резиденцією, що теж робило його осередком влади.

Деякі топоніми надають пареміям відтінку казковості й потойбічності. Значення топоніму Дунай у паремії Зайхав за Дунай - та й додому не думай $[14$, с. 205] може бути трактоване не як назва річки, а як кордон між двома світами - світом живих і світом мертвих. У давніх українських народних піснях топонім Дунай вживається на позначення якоїсь чарівної країни, тридев'ятого царства, вирію. За багатьма легендами Дунай тече посеред раю.

Але не завжди значення всієї паремії випливає зі значення конкретного топоніма. Іноді він $є$ лише певним абстрактним просторовим орієнтиром. Наприклад, у пареміях Дон Доном, а найкраще дома [14, с. 201], Провадь мене і до Вєни, а не зробиш пана з мене [14, с. 203], Заїхав за Дунай - та й додому не думай [14, с. 205] топоніми мають значення «іноземності», якогось іншого місця. У пареміях I в Києві, $і$ в Харкові всюди злидні однакові [14, с. 30], Піди до Кракова, всюди біда однакова; піди і за Карпати, то треба бідувати [14, с. 42], Від Києва до Кракова - всюди біда однакова [14, с. 42], Пани однакові, щчо в нас, щзо в Харкові [14, с. 109], Попи однакові, щуо в нас, що в Кракові [14, с. 222], Іди, зима, до Бучина, бо вже нам надокучила [14, с. 240], Дурний $і$ в Києві не купить розуму [14, с. 392], Отже, у Києві були, та і там розуму не придбали [14, с. 392], За дурним нічого в Київ їхати, вони і тут $\epsilon$ [14, с. 392], Дурень до Києва, дурень і з Києва [14, с. 392] топоніми мають значення «інше місце», «усюди» або «ніде» в разі заперечення тощо.

Деякі топоніми були вигадані з метою закцентувати на тому чи іншому аспекті життя або характеру людини. Наприклад, у паремії $A$ ви часом не з Брехунівки [14, с. 171] топонім Брехунівка утворено від слова брехун за допомогою суфіксів -ів- і - $\kappa$ - і вжито з метою підкреслити ваду людини.

Окрім цього, паремії можна погрупувати за семантичним критерієм відповідно до того, про який аспект людського життя в них ідеться:

1. Життя бідних людей (I у Відні люди бідні [14, с. 15], Що таке Америка, спитай у Каленика: їздив по гроші, а привіз гниди та воші $[14$, с. 15], I в Києві, і в Харкові - всюди злидні однакові $[14$, c. 30$])$.

2. Бідування (На кого біда нападе, то до Києва йде; а як біда минеться, то він $і$ з Броварів вернеться [14, с. 42], Піди за Бескиди - не збудеш біди [14, с. 42], Піди і за Карпати, то треба бідувати [14, с. 42], Від Києва до Кракова - всюди біда однакова $[14$, с. 42]).

3. Соціальна нерівність (Ой на річиі, на Йордані, нема хліба, підем далі [14, с. 74]).

4. Чумацтво (Гола та Теплинський ліс, де чумаків бере біс [14, с. 91], Но! 3 долини в долину та на всю Украӥну [14, с. 91]).

5. Боротьба проти соціального гноблення (Пани однакові, щзо в нас, щуо в Харкові [14, с. 109]).

6. Надії на краще життя (Пішов на Вкраїну, на степи, на вольні землі [14, с. 155]).

7. Засудження брехні ( $A$ ви часом не з Брехунівки [14, с. 171], Прийшли з Бозни та чорзна-що верзли [14, с. 174], Не добереш, де Рим, де Крим, де попова груша [14, с. 174], На Поділлю хліб по кіллю, а ковбасами хліб загороджений [14, с. 175]).

8. Щастя та недоля (Нещасна, як подільська корова $[14$, с. 185]).

9. Захист батьківщини, про козаків (історичні) (Дон Доном, а найкраще дома [14, с. 201], Або будем на Русі, або пропадемо усі [14, с. 201], Як хан долізе до Криму [14, с. 203], Бідний, бідний пане Степане! Не попав, небоже, на Запоріжжя, не найшов гаразд шляху [14, с. 203]).

10. Погляди народу на віру (Підеш до Печери - ляжеш спать без вечері [14, с. 214], Попи однакові, щзо в нас, щуо в Кракові [14, с. 222]). 
11. Українські міста (Не зразу Львів збудовано [14, с. 288], Старший Галич відо Львова [14, с. 288], В Луиьку все не по-людськи: навколо вода, а всередині біда [14, с. 288], Сосниия - розкішниия, великі вжитки: кругом вода, а всередині біда [14, с. 288], Кам'янещь - вінець: кругом вода, а всередині біда [14, с. 288], Городня - голодня [14, c. 288]).

12. Розум і мудрість (I на мудрім дідько на Лису гору їздть [14, с. 324]).

13. Пороки й вади людей (Що бішена кішка, що понеділкова жінка, щзо чоловік з Боришполя все одно [14, с. 343], Дурний $і$ в Києві не купить розуму [14, с. 392], Отже, у Києві були, та і там розуму не придбали [14, с. 392], За дурним нічого в Киї їхати, вони і тут є [14, с. 392], Дурень до Києва, дурень і з Києва [14, с. 392]).

14. Їжа (Вези овес і до Парижа, а не буде з вівса рижа [14, с. 584]).

15. Гостювання та частування (Я не до вас, я до Дунаю: водииі нап'юся, та й додому піду $[14$, c. 685$])$.

Отже, усі топоніми можуть бути погруповані за семантикою, а паремії 3 топоономастичним компонентом - за змістом відповідно до сфери життя, яку вони описують. Їхнє значення може залежати від прямого значення топоніму, що входить до їх складу, або від історичного контексту, в якому цей топонім зазвичай уживають. Також на загальну семантику паремії впливають ті відтінки значення, якими народ самостійно наділяє ті чи інші топоніми. Значення самого топоніму в межах тієї чи іншої паремії може бути не конкретним, а абстрактним і вказувати на певну просторову належність чи, навпаки, iї відсутність.

Висновки й перспективи подальших розробок. Серед паремій із топонімічним складником переважають багатокомпонентні конструкції. Римована структура багатьох паремій зумовлена потребою в їх легкому сприйнятті й запам'ятовуванні. Топоніми у складі паремій найчастіше виражено називним, родовим, знахідним і місцевим відмінками іменників.

Значення паремій може залежати від прямого значення топоніму, що входить до їх складу, або від історичного контексту, в якому цей топонім зазвичай уживають. Також на загальну семантику паремії впливають ті відтінки значення, якими народ наділяє ті чи інші топоніми. Значення самого топоніму в межах прислів '̈в і приказок не завжди точно вказує на місце, яке він позначає в реальності. Воно може бути абстрактним і вказувати на певну просторову належність чи, навпаки, iï відсутність, як-то «інше місце», «усюди» або «ніде» в разі заперечення.

Проблематику подальших розробок убачаємо в усебічному структурно-семантичному аналізові власне фразеологізмів.

\section{ЛIТЕРАТУРА}

1. Демський М. Т. Прислів'я. Украӥнська мова: енциклопедія / редкол. В.М. Русанівський, О.О. Тараненко, М.П. Зяблюк та ін. Київ : Українська енциклопедія, 2004. С. 530.

2. Демський М.Т. Приказка. Украйнська мова: енциклопедія / редкол. В.М. Русанівський, О.О. Тараненко, М.П. Зяблюк та ін. Київ : Українська енциклопедія, 2004. С. 524.

3. Демський М.Т. Пареміологія. Украӥнська мова: енциклопедія / редкол. В.М. Русанівський, О.О. Тараненко, М.П. Зяблюк та ін. Київ : Українська енциклопедія, 2004. С. 460.

4. Бойко В.М., Давиденко Л.Б. Структурно-семантичні особливості фразеологічних одиниць 3 анімалістичним компонентом. Література та культура Полісся. Вип. 36 : Історія та культура Полісся у загальноукраїнському контексті / відп. ред. і упоряд. Г.В. Самойленко. Ніжин : Видавництво НДУ ім. М. Гоголя, 2007. С. 3-8.

5. Пономарьова О.А. Назви людей за родом занять як ключові смислотворчі компоненти фразеологічних одиниць. Умань : Візаві, 2019. $220 \mathrm{c}$.

6. Каракуця О.М. Фразеологізми української мови 3 компонентом «душа» (структурно-семантичний, ідеографічний, лінгвокультурологічний аспекти) : дис. ... канд. філол. наук : 10.02.01. Харків, 2002. 212 c. URL: https://bit. ly/3z9tujr (дата звернення: 13.09.2021).

7. Ужченко В.Д. Семантика українських зоофразеологізмів в етнокультурному висвітленні : автореф. дис. ... канд. філол. наук : 10.02.01. Харків, 2000. 18 с.

8. Мороз О.А. Фразеологізми 3 топонімами в українській мові. Лінгвістичні студї : збірник наукових праць. Вип. 4. Донецьк : ДонДУ, 1998. C. 163-171.

9. Мороз О.А. Фразеологічні одиниці 3 компонентом «власне ім'я» в сучасній українській мові: структурно-семантичний аспект : дис. ... канд. філол. наук : 10.02.01. Донецьк, 2002. 288 c. URL: https://bit.ly/2VIGPlc (дата звернення: 23.09.2021).

10. Омельяненко О.В. Українські фразеологізми 3 компонентами-соматизмами як засоби вербалізації танатологічної семантики. Лінгвістичні дослідження. 2013. Вип. 36. С. 44-51. URL: https://bit.ly/3kdpTgf (дата звернення: 13.09.2021).

11. Куцик О.А., Колечко М.Д. Антропоніми i топоніми як смисловий центр паремій із семантикою «життєві ситуації». В. Даль в мировой культуре : сборник научных работ. Ч. II. Луганск - Москва, 2012. С. 220-229.

12. Куцик О.А. Прислів'я і приказки з ономастичним компонентом як лінгвокультурні тексти 
(на матеріалі російської та української мов). Рідне слово в етнокультурному вимірі. 2013. C. 176-186. URL: https://bit.ly/3hCq6HV (дата звернення: 04.10.2021).

13. Ковальська Н.А. Ономастичний простір паремій. Мова і культура : наукове видання. Київ : Видавничий Дім Дмитра Бураго, 2005. Вип. 8. Т. III. Ч. 2. Лінгвокультурологічна інтерпретація тексту. Теорія і практика перекладу. С. 108-113. URL: https://bit.ly/2VJR0G9 (дата звернення: 04.10.2021).

14. Бобкова В.А., Багмут Й.А., Багмут А.Й. Українські народні прислів'я та приказки. Київ : Державне видавництво художньої літератури, $1963.792 \mathrm{c}$.

15. Жучкевич В.А. Общая топонимика. Минск : Высшая школа, 1980. 287 с.

16. Бевз Г.П. Історія Уманщини. Київ : [б. в.], 1997. $104 \mathrm{c}$.

\section{REFERENCES}

1. Demskyi M.T. Pryslivia. Ukrainska mova: entsiklopedia [Proverbs. Ukrainian Language: Encyclopedia] (eds. V.M. Rusanivkyi, O.O Taranenko, M.P. Ziablyk). Kyiv : Ukrainian Encyclopedia, 2004. [in Ukrainian].

2. Demskyi M.T. Prykazka. Ukrainska mova: entsiklopedia [Ukrainian Language: Encyclopedia] (eds. V.M. Rusanivkyy, O.O. Taranenko, M.P. Ziabliuk). Kyiv : Ukrainska entziklopediya, 2004. [in Ukrainian].

3. Demskyi M.T. Paremiologia. Ukrainska mova: entsiklopedia [Ukrainian: Encyclopedia] (eds. V.M. Rusanivkyi, O.O. Taranenko, M.P. Ziablyk). Kyiv : Ukrainian Encyclopedia, 2000. [in Ukrainian].

4. Boiko V.M., Davydenko L.B. Stukturnosemantychni osoblyvosti frazeologichnyhodynyts z animalistychnym komponentom [StructuralSemantic Peculiarities of Phraseological Units With Animalistic Component] Literatura $i$ kultura Polissia vol. 36: Istoriya i kultura Polissia $\mathrm{V}$ zagalnoukrainskomu konteksti (eds. N.V. Samoilenko), Nizhyn: Nizhyn State University of M. Gogol, 2007, pp. 3-8.

5. Ponomarova O.A. Nazvy liudei za rodom zaniat yak kliuchovi smyslotvorchi komponenty frazeologichnyh odynytz [Naming of People According to Their Occupation as the Main Sense Creating Components of Phraseological Units] Uman: Vizavi, 2019. [in Ukrainian].

6. Karakutsia O.M. (2002) Frazeologizmy ukrainskoi movy z komponentom "dusha" (strukturno-semantychnyi, ideografichnyi, lingvoculturologichnyi aspekty) [Ukrainian Phraseologisms With "Soul" Component
(Structural-semantic, Ideographic, Linguocultural aspects)] (PhD Thesis), Kharkiv, URL: https://bit.ly/3z9tujr (accessed: 13 September 2021).

7. Uzhchenko V.D. (2000) Semantyka ukrainskyh zoofrazeologizmiv v etnokylturnomy vysvitlenni [Semantics of Ukrainian zoophraseologisms in Ethnocultural Spectrum]: (PhD Thesis) Kharkiv.

8. Moroz O.A. Frazeologizmy $\mathrm{z}$ toponimamy $\mathrm{v}$ ukrainskii movi [Phraseologisms With Toponims in Ukrainian]. Lingvistychni studii [Linguistic Studies]: vol. 4, Donetsk : Donetsk State University, 1998. pp. 163-171.

9. Moroz O.A. Frazeologichni odynytzi z komponentom "vlasne imiya" v suchasnii ukrainskii movi [Phraseological Units With «Proper Name» Component in Modern Ukrainian: Structural-Semantic Aspect] (PhD Thesis), URL: https://bit.ly/2VIGPlc (accessed: 23 September 2021).

10. Omelianenko O.V. Ukrainski fraseologizmy z komponentamy-somatyzmamy yak zasoby verbalizatzii tanatologichnoi semantyky [Ukrainian Phraseologisms With Componentssomatisms as Means of Verbalization of Tanatologic Semantics]. Lingvistychni doslidzhenniya. 2013, vol. 36, pp. 44-51. URL: https://bit.ly/3kdpTgf (accessed: 13 September 2021)

11. Kutsyk O.A., Kolechko M.D. Antroponimy i toponimy yak smyslovyi tzentr paremii iz semantykou "zhyttevi sytuatzii" [Anthroponyms and Toponyms as a Sense Center of Paremias With "Life Situations" Semantics]. $V$. Dal v mirovoi culture, ch. II. Lugansk - Moscow, 2012, pp. 220-229.

12. Kutsyk O. Pryslivia i prykazky z onomastychnym komponentom yak lingvokyltyrni teksty (na osnovi rosiiskoi na ukrainskoi movy) [Proverbs and Sayings With Onomastic Component as Linguo-Cultural Texts (on the Basis of Russian and Ukrainian]. URL: https://bit.ly/3hCq6HV (accessed: 4 October 2021).

13. Kovalska N.A. Onomastychnyi prostir paremii [Onomastic Area of Paremias] Elekntonnyi resurs. URL: https://bit.ly/2VJR0G9 (accessed: 4 October 2021).

14. Boikova V., Bakhmut I., Bakhmut A. Ukrainski narodni pryslivia ta prykazky [Ukrainian Folk Proverbs and Sayings], Kyiv: State Publishing of Fiction, 1963, 792 p. [in Ukrainian].

15. Zhuchkevich V. Obshchaya toponimika [General toponymy]. Minsk: High School, 1980. 287 p. [in Russian].

16. Bevz G. Istorya of Umanshyny [History of Uman region]. Kyiv : [b. v.], 1997, 104 p. [in Ukrainian]. 